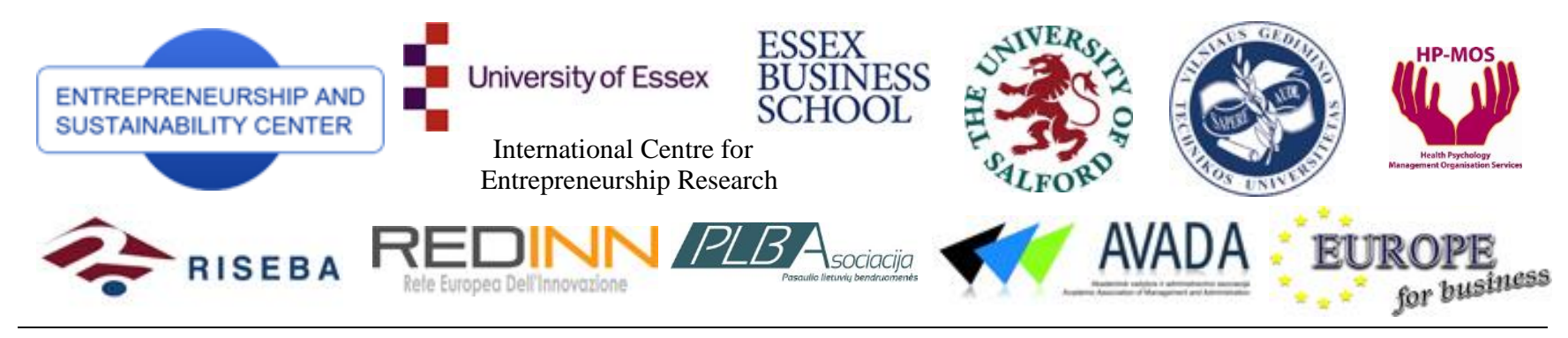

ENTREPRENEURSHIP AND SUSTAINABILITY ISSUES

ISSN 2345-0282 (online) http://jssidoi.org/jesi/aims-and-scope-of-research/

\title{
RISE AND FALL OF THE LYON SILK CLUSTER: A CASE STUDY ABOUT ENTREPRENEURIAL SUSTAINABILITY
}

\author{
Pierre Bonetto $^{1}$, Bernd Hofmann², Gunnar Prause ${ }^{3}$ \\ 170 Grande rue de la Croix-Rousse, F-69004 Lyon, France; \\ ${ }^{2}$ University Claude Bernard Lyon 1, IUT Lyon 1, Dépt. GEA, 1 rue de la Technologie, \\ F-69622 Villeurbanne Cedex, France; \\ ${ }^{3}$ Tallinn University of Technology, Akadeemia tee 3, 12618 Tallinn, Estonia \\ E-mails: ${ }^{1}$ pierre649@wanadoo.fr; ${ }^{2}$ bernd.hofmann@univ-lyon1.fr; ${ }^{3}$ gunnar.prause@ttu.ee
}

Received 26 March 2014; accepted 30 June 2014

\begin{abstract}
Innovation is the key driving factor for economic growth and social wealth. Already Joseph Schumpeter emphasized the importance of innovation for entrepreneurial activities by incessantly revolutionizing economic structures in order to get better or more effective processes and products. So a lack of innovation may quickly lead into business failure or - even on a sectorial level - loss of market positions. An actual example is the textile design sector located in the city of Lyon, which rose together with the Lyon silk industry for centuries and collapsed and nearly disappeared nowadays, although it occupied the world leader position up into the 1970ies (Bonetto et al. 2014). Innovation is the specific tool for entrepreneurs to exploit business opportunities and innovation is also one of the key driving factors for economic grow and social wealth. Innovative products and services emerge more often as a result of cross-sectorial combination of technologies, design and business models, especially in the context of regional clusters (Drucker 1985). Already Joseph Schumpeter emphasized the importance of innovation for entrepreneurial activities by incessantly revolutionizing economic structures in order to get better or more effective processes and products. His famously words concerning "creative destruction" stressed already the close links between entrepreneurship, innovation and design (Schumpeter 1911). Numerous articles of scholars discuss how innovation procures substantial income on the international markets and allow benefiting from competitive advantages.

This paper will focus on the fact how lacking investment in innovation and specific business culture lead to situations where disadvantages take a cumulative character which strengthens the process of decline of economic competitiveness and loss of market shares. In the case study about the life-cycle of the French silk industry and its related entrepreneurial activities in the area of textile design in the city of Lyon, it is illustrated how a lack of innovation related with a specific entrepreneurial behavior is leading to a collapse of the whole sector, which, until the 1970ies, occupied a world leading position in this field. The case study is based on interviews of experts and actors involved in this business, witnesses to the activity's collapse, on desktop research and the study of documents which analyze the evolution to the currently existing situation. Currently, only isolated persons continue on a free-lance basis the traditional activity, most of them close to retiring age. A few companies, with significantly reorganized activities do as well continue their activity.
\end{abstract}

Keywords: innovation, entrepreneurship, cluster life-cycle, sustainability, textile-design

Reference to this paper should be made as follows: Bonetto, P.; Hofmann, B.; Prause, G. 2014. Rise and fall of the Lyon silk cluster: a case study about entrepreneurial sustainability, Entrepreneurship and Sustainability Issues 2(1): 1-11.

DOI: $\underline{\text { http://dx.doi.org/10.9770/jesi.2014.2.1(1) }}$

JEL Classifications: L67, O310 


\section{Introduction}

Hayek (2002) stresses that innovation and research in the 21st century are increasingly becoming international endeavors and most innovations originate from multiple sources, with many drawing in components or technologies developed in multiple locations. Foray et al. (2011) explain that, the potential evolutionary pathway of this innovation system is dependent on inherent structures and existing dynamics that have to do with the adaptation of radical transformation. Zhao (2005) studied the relationship and interaction between entrepreneurship and innovation and pointed out that the organizational culture and the management style are crucial factors affecting the development of entrepreneurial and innovation behavior in organizations. In recent studies Classen et al. (2013) focus on differences of attitudes towards innovation investment in family and nonfamily SMEs, or Rauch et al. (2013) analyses the attitudes towards innovation linked to national cultures of business owners.

So today, innovation is increasingly complex, fast, interactive, and requires the connection of external and internal knowledge bases (Chesbrough 2003). Companies acquire knowledge from a variety of different sources and actors and combining it with internal and localized knowledge and expertise since which is crucial for competitiveness as innovation processes in the interplay between local and complementary global knowledge (Porter 2000; Gertler and Levitte 2005; Boschma and Ter Wal 2007; Laužikas, Mokšeckienė 2013; Išoraitė 2013; De Alencar, Almeida 2013; Wahl, Prause 2013; Tvaronavičienė 2014; Dzemyda, Raudeliūnienė 2014; Bileišis 2014; Išoratè et al. 2014; Wahl 2014; Figurska 2014; Litvaj, Poniščiaková 2014). Despite the multitude of insights into technology transfer, remarkably little is known about how transfer processes are shaped by the underlying industry and its technical regimes (Breschi et al. 2000; Marsili 2001; Gilsing et al. 2011; Korsakienè 2013; Giriūnienè 2013; Korsakienè, Tvaronavičienè 2014).

Geographic approaches to innovation have also long been discussed in the management literature and go back to contributions like Porter (1998), Jaffe et al. (1993) or Anselin et al. (1997). The region and its clusters moved into the focus of attention to systematically study innovation activities (Cooke and Morgan 1998; Porter 2000). Other scholars emphasize beyond geographical settings and spatial aspects also the external environment which influences heavily regional development and its networks (Florida 2002; Bluhm 2008). The emergence of regional innovation networks together with the roles of involved stakeholders and related success factors have been studied intensively by other scholars (Goddard 2000; Meier zu Köcker 2008). But most contributions study well performing regions and emerging clusters whereas the consideration of the full cluster life-cycle represents a rather neglected research topic.

This is of special interest for the understanding why the silk cluster and the related textile design sector in the French city of Lyon which, until the 1970ies occupied a world leading position in this field, collapsed due to a lack of innovation and its special entrepreneurial culture. Currently, only a few textile design entrepreneurs and design companies continue the traditional activity, most of them close to retiring age. This case study witnesses an important example of cluster life-cycle over a longer period of some centuries combined with forms of "unsustainable entrepreneurship" which represents a counterexample for the Lisbon strategy, formulated in 2000 by the European Union in order "to become the most competitive and dynamic knowledge-based economy in the world, capable of sustainable economic growth with more and better jobs and greater social cohesion". This commitment is renewed under the EU 2014-2020 budget framework. National governments and subnational territorial structures backed these goals including France and the French Rhône-Alpes Region, which has voted in 2013 its SRI-SI plan (Regional innovation strategy - intelligent specialization).

The insights of this paper express the fact that cluster development based on closed innovation understanding and lacking investment in innovation together with an auto centric business culture lead to strategic disadvantages, a decline of competitiveness, loss of market shares and finally the fall of the entire cluster including all related entrepreneurial activities. As a consequence in the Lyon situation of Schumpeter's "creative destruction" process the silk cluster and its textile design entrepreneurship sector moved from France to other destinations. 


\section{Literature review}

Innovation management is usually associated with processes. As coined by Schmitt-Grohe (1972), these processes incorporate three key phases: idea generation (1), idea analysis (2) and idea implementation (3) (Schmitt-Grohe 1972: 52). On the basis of these observations, Benkenstein (1998) has proposed the following innovation management concept, so-called innovation funnel. By drawing in his observations, the innovation management model includes four stages: idea generation (1), research, development and conception (2), product and market test (3) and implementation (4).

Following Bartl (2008), open innovation is referred to the concept, which underscores the way of going beyond the corporate boundaries, i.e. an active strategic deployment of environmental clout or external factors of influence to increase its own innovation potential. Crucial determinants of such concept are the shift from the industrial society to the network-based knowledge and communication society. As a result, innovation occurs and ideas are generated in such a society through the interactive creation of value. Additionally, open innovation encompasses such manifestations as to be open for the knowledge of the other, generation of the knowledge as a joint action as well as the share of the knowledge with the other. Besides, an important role for the phenomenon open innovations plays the customer. In the course of innovation management, there was generated a new role model of the customer when developing new products or offering new services. In this sense, open innovation emerges also when the customer is involved into the process of generation. Therefore, it is vital to adapt to customer's needs and requirements as well as wishes in the customer goods markets. Furthermore, it is essential to integrate the customer into the entrepreneurship innovation-related activities as a new external knowledge and ideas source (Bartl 2008: 3-4). Zhao (2005) confirmed that entrepreneurship and innovation are positively related to each other and interact to help an organization to flourish, i.e. entrepreneurship and innovation are complementary, and a combination of the two is vital to organizational success and sustainability. He also pointed out that the organizational culture and the management style are crucial factors affecting the development of entrepreneurial and innovation behavior in organizations.

Sustainable entrepreneurship is a relative new concept, which can be distinguished from economic and social entrepreneurship by stressing the efficiency and effectiveness in an inter-generational economic consideration for the future (Young and Tilley 2006: 402). Thus, sustainable entrepreneurship is in line with entrepreneurs heading for profit and improving environmental sustainability and social conditions, i.e. considering the long-term economic and business consequences of new venture opportunities (Cohen and Winn 2007: 35). One important problem of the on-going discussions about sustainable entrepreneurship is that the existing concepts are rather oriented on the needs and the situation of larger companies than on reality of the SME sector. When it comes to the implementation of sustainable entrepreneurship concepts, Gerlach (2003) proposes three strategies to reach sustainability in the context of entrepreneurship based on sufficiency, efficiency and consistency. Taking a closer look at theoretical concepts and approaches under scrutiny, these tend to interface at the respective points or to address same or similar questions from the corporates perspective. For instance, interdisciplinary nature, idea generation and implementation (Brown 2008; Benkenstein 1998), a broader view on the enterprise (internal and external factors), needs for solving problems, intertwined and on-going process from the fields of design, technology or innovation, and business, the sustainability factor etc. have been located in particular discourses regarding these concepts.

Pascual et al. (2011) point out that process of designing, developing and implementing solutions should follow some of five key points including the observation that (1) sustainable development is a process and not an end, that (2) sustainability requires incremental and continuous improvement, that (3) not always everything can be achieved, that (4) the "Holy Grail" of sustainability does not exist, that (4) individual consumer benefits have to be linked to social and environmental benefits and that (5) functionality equals impact. Finally geographic and cluster related approaches in the context of innovation have been discussed over a long time in the management literature and go back to contributions like Porter (1998), Jaffe et al. (1993) or Anselin et al. (1997). Especially the New Economic Geography (Krugman 1991, Fujita and Krugman 2004) discusses agglomeration processes and economies of scales generated through specialization. So the region and its clusters moved into the focus of attention to systematically study innovation activities (Cooke and Morgan 1998; Porter 2000). Most contributions 
study very well performing regions and clusters, but they neglect that clusters underlie also life-cycles, especially the decline of clusters have not been in the centre of entrepreneurial cluster research (Sölvell 2008; Lindqvist $e t$ al. 2013).

\section{Methods}

The paper describes a case study of the development of the silk sector with a focus on the textile-design entrepreneurial activities in Lyon within the last 50 years. A special focus is laid on organisational, cultural and innovation topics which were related to important stages in the Lyon silk industry. The research process described in the paper has pursued a manifold research path, whereby diverse research methods have been combined with the respective research approach and research tool. Five techniques were employed in exploring the objectives of the present paper. Research types: analytical, qualitative, historical, empirical, and practice-based. Research approach: qualitative. Research methods: descriptive and qualitative - case studies, semi-structured interviews, expert assessments and observations. Research scope: different research activities between spring 2013 and spring 2014. The reasoning behind the selection of the following techniques in the research process is elaborated in the following. Regarding the research types, the paper has chosen analytical, qualitative, empirical and practice-based way, since during the research process the facts and empirical evidence gathered were appropriately analysed and subject to a critical assessment. The core of the research process is the qualitative research approach. Important insight views were given in qualitative experts interviews with still active textile designers in Lyon where the interviews with Pierre Bonetto and Marc Terrier contributed outstandingly to the understanding of the case study about the textile design sector in Lyon (Bonetto et al. 2014).

\section{The silk industry in Lyon}

Textile industry is a major sector of activity in Lyon since its roots in the 15th century. It developed into a vertical cluster, which reached several times a climax period (late 18th century, second half of the 19th century, between the two world wars under an already strongly adapted structure), including supply of raw material, production and distribution, essentially through export. The historical description of the development of the Lyon silk industry is based on the studies of Anne Marie Wiederkehr (Wiederkehr 1981).

At different stages of the existence of this industry, institutional support via tax and production privileges or through support to innovation can be considered to be key factors for the commercial success of Lyon-made textile, especially silk. The very beginning of silk production in Lyon is due to a royal order issued to the local citizens to establish and finance silk weaving workshops in their city (Regulation of 23.11.1466, issued by King Louis XI; Wiederkehr 1981). The aim is to avoid money transfers out of France to pay imports of essentially Italian made silk products highly appreciated by French aristocrats and negotiated on the important Lyon fare. The failure of this first trial appears to be the lack of size of the activity thereby generated, making it unable to stand price competition.

A renewed attempt in the 1530ies granted tax freedom and privileges to Italian merchants planning to establish workshops in Lyon. In this frame, the city was granted the monopoly of import of raw silk thread. This time the establishment of a structured, competitive activity succeeded, the Italian and French production of low range silk products was gradually replaced by products made in Lyon. The vertical cluster of a whole, interlinked, production sector appeared after the upheavals of the second half of the 16th century only. Again due to royal desire to master the entire production chain, silk farms where established in the southern part of France, supplying Lyon with raw material. Introduction, from Italy, of adequate knowledge and technology, allowed the Lyon based workshops to increase the sophistication- and quality-level of local production meant essentially to furnish the French Royal House and important aristocrats.

The reputation of French taste, going along with the rank of France as cultural trend setter among the aristocratic societies of Europe allowed the French silk industry to develop into a highly performing, innovative and economically important production sector. The support to innovation grew into institutional forms, granted either by the guild or by the municipal authorities in cooperation with royal representatives and financed on customs 
levied on textile imports. This structured system of support to improvement of technology and design involved in increasing manner cooperation between both public and professional authorities. It is interesting to see in the case of the Lyon silk industry, how over a long period a given industry, with the help of professional and public authorities was able to become competitive and further, predominant in Europe. On the foundations of this stronghold the sector throughout the 19th century was able to maintain its place and proofed to be capable to undergo the necessary evolution to cope permanently with market requirements and technological evolution. By the end of the 19th century pure silk lost its importance and was successfully replaced by mixed products and later artificial fibers, which allowed increasing the number of social groups able to afford products of this industry. About $80 \%$ of the regional production was exported. The USA and Great Britain were by far the most important markets, buying $3 / 4$ of the production. Only very recently, during the 1970 the final decline process started and led within 30 years to the vanishing of the entire sector in Lyon.

Before the start of the phenomenon of mechanization of this sector, in the 1860ies, Lyon had about 180000 inhabitants and roughly 30000 looms. This single figure may provide an impression of the high importance of this sector. Evidently, it was not limited to the municipality of Lyon, but made off an important portion of the regional economy, workshops and direct sector-related activities were exercised within a range of about $60 \mathrm{~km}$ of Lyon, not to speak of the silk thread production in the Southern part of France.

The core of the Lyon silk fabric, production and distribution, involved a system of four groups of specialized participants which formed during the prerevolutionary era: Merchants, mastering the supply of raw silk threat and being in contact with the final customer, furnish local merchant-producers with raw material and orders. This group employs the designers, work-shop owners, delivers raw material to the workshops and sells the production to the merchants. Workshop owners produce up to the orders received, without being able to master neither design, nor supply or sale, be it on the level of goods or prices. The fourth group is the most numerous people, the silk workers employed and paid by the workshop owners. The latter two groups where entirely depended on the two groups on top of the pyramid. Further elements of this vertical cluster organization were floriculturists, colorproducers, engravers, printers, and still further specialists, all of them contributing to the functioning of this industrial sector.

\section{Textile design entrepreneurship in Lyon}

The textile design entrepreneurship activities were an integrated part of the Lyon silk sector, but with a certain independence from its core activities in silk industry. The designers occupied a status of highly skilled independent workers, rather artists, employed by the merchant-producers, but often held themselves parts of the share capital of these establishments. The designs, once they were accepted by the client, became part of the property of the latter. Insofar, designers were also dependent participants in the system. Nevertheless they insured the success of the entire sector by delivering designs which with time created an essential part of the reputation of the Lyon fabric system (Bonetto et al. 2014).

The design sector, up to the results of interviews of two of the last still exercising members of this profession, was a very dynamic part of the system. In the 1970 it was itself structured in form of a cluster organization with about 60 studios of which an important proportion was located in a very narrow sector of down-town Lyon. Most of the studios were very small entities, headed by the owner - rarely a designer himself, rather a commerce-focused professional. Due to French labor regulations created in 1936, re-established in 1946, an enterprise with more than 10 employees needs to accept the election of personnel's delegate representing the employees in front of the employer and being equipped with granted rights of information and expression of proposals. In order to avoid such forms of rights for the personnel, many employers, not only in the textile sector, voluntarily stopped hiring before their enterprise reached the relevant size. Therefore a lot of studios occupied personal, partly under employee status, partly under independent worker-status. Under the direction of the owner the head of the workshop, mostly a former designer himself, called "chef d'atelier", coordinated and managed the work of the designers and they were responsible for the collections of the studios. Even if the textile design was limited by standards forms the driving force in the studios was creativity on a high competitive level and each studio had their own style, brand and market niche and it was possible to differentiate between the studios. 
The close neighborhood of many of these design studios allowed a very fluid functioning of this particular labor market. Designers easily quit one studio to be hired directly by another one. Most of the studios had their particular style or sectorial specialization and even though competition existed, the market was large enough for successful doing business of all of them. The high level of labor fluidity insured mutual inspiration. Nevertheless the level of individualism and competition between the designers of a studio was high, due to the sales-related model of remuneration. An employed designer received a part of his salary as a determined, fix amount, generally close to the minimum wage. As a counterpart he had to successfully produce a given number of designs over a month. Any sold design above this minimum level reported to him $1 / 3$ of a determined value. Freelance designers received no fix remuneration but $50 \%$ of a determined value per design they produced. The designers ignored the sales price of their works.

This model contributed to the absence of organization of the work-force under the roof of trade-unions, which would have been inacceptable to the studio-owners who believed in a highly patriarchic form of management. The standing and the dynamics of the Lyon market was as strong as to attract customers from all over the world, especially United Kingdom, United States, Japan and Italy to make their commercial visits directly in the studios. Several visits in one studio per day were not exceptional. Customers took advantage from the proximity of the studios by scheduling a series of contacts and purchase meetings. Furthermore sales trips were regularly made by the studio-owners to visited customers abroad. Presentations in high class hotels in Paris and participation in trade fairs became additional occasions for sales once the process of decline had already set in. Together with the municipal administration the professional sector had set up a structured three-year training curriculum for future designers. A special "Textile High-School" (Lycée Didérot) functioned in Lyon in order to enable the sector to cope with demand. The curriculum was organized such that $50 \%$ of a pupil's time was dedicated to theoretical training in the school and $50 \%$ of the time was practical on-the-spot learning in a design studio.

\section{Decline and collapse}

The era of success finished in the 1970ies, when economic fundamentals changed and made clearly appear the need for reorganization and restructuration of a series of mature sectors in the developed countries, among them as one of the first the textile sector. During the early half of the 20th century, the design sector had already known a very strong evolution, leaving the initial dedication to the silk production by designing essentially for the current production of various textiles.

The starting point of the changes of the late 20th century which underwent the textile design sector was described by the interviewed designers to be the period of the petrol-shocks, symbols for the end of a 30-year-long period of growth since 1945. In parallel, several evolutions were on their way: delocalization for low-cost countries like Morocco and Turkey in the textile producing sector took place. They took off the market part of the demand for design, but despite the fact that silk production decreased in Lyon, the textile design sector in Lyon was able to continue its activities

But this new business environment for the textile designers changed the way of marketing how design samples were presented to potential customers: British designers, often trained as interns in the Lyon studios, offer showroom presentations instead of the traditional catalogues and paper-samples, Italian design studios use modern technology to offer a high quantity of design samples at lower prices. Lack of recognition of the new trends and incapacity to adopt to the new evolutions, in parallel to the shrinking market lead to price competition which attacked traditional Lyon based design studios, first those which were the most fragile ones, but more and more also the core segment of the formerly dominating Lyon cluster.

A smaller and smaller number of players left over led to a less and less fluid situation also for the designer labor market. Employment opportunities for young designers start to lack, numbers of applicants for the training center at Lycée Diderot decrease, until the decision is taken in the 1980 to stop the training curriculum. A last effort to revitalize a modernized curriculum was undertaken between 1990 and 1993 before the final abandon. Currently, up to one of the interviewed persons, only three textile design-studios are left over in Lyon, all of them exercising 
in niche markets, waiting for the time to come, when retirement of the owner will definitely close the chapter of Lyon based textile design. Today, adapted to the new situation on the textile markets, these studios stripped themselves off, as far as possible, of their cost-generating structures: rather the use of free-lance cooperation than traditional employment, use of modern design technology for small, specialized market segments, as competition against larger design studios from abroad appears to be out of reach. An expressed regret is the lack of structured and durable public support for this activity; especially as far as the efforts of making the products known through participation in fares and presentations is concerned. This lacking support is described to be an additional obstacle for the surviving firms, fragile on the financial level, which can only afford with difficulties the communication and promotion costs needed to be invested to get known by potential customers.

\section{Specific findings}

This case study, as described in a congruent manner by two textile designers which still do exercise their profession, makes appear structures which are close to the descriptions given by Alfred Marshall on "industrial districts" and which are related in a more recent version to the definition of clusters (Marshall 1920; Porter 2000). The Lyon textile sector during the era of its apogee was maybe even closer to the Italian version of the industrial districts as put into the light by Giacomo Becattini (2002). When writing "However, one thing should be quite clear: the notion of the division of labor is here not referred to a single company, as in Smith's example of the needle factory, nor to the market in its abstract totality, as in Young's model, but to an intermediate, mesoeconomic entity that perhaps lacks a legally recognized status and aggregates and disaggregates in its different manifestations - territorial and otherwise - in response to overall long run changes in socio-economic relationships at both the local and global level.", the author seems to underline what happened to the former Lyon based textile design activity, organically appeared on the market together with the silk and textile cluster : the structures of this industry became global, they lost their identification with a given territory, but still do exist, elsewhere, differently structured and organized, but still capable to deliver a given product : textiles in various forms and qualities, for various uses.

Anne-Marie Wiederkehr (1981) showed in her analysis of the manual for silk designers "Le dessinateur pour les fabriques d'étoffes d'or, d'argent et de soie" of Nicolas Joubert de l'Hiberderie (published in 1765), that already during the 18th century clear and precise knowledge and recognition existed about the interaction of markets and competitors on these markets (Miller 2004). People, 250 years ago were precisely aware about the risks and opportunities of internationalization of economic activities and the issues of communication or secrecy on data and information about activities. The question of innovation opportunities through open information existed just at it is a very contemporary issue of the early 21 st century.

Anne Marie Wiederkehr writes “... les tenants de l'ordre établi qui veulent le maintien de leurs privilèges (Noblesse, Haut-Clergé) ou de leurs monopoles (Corporations), jugent les diffusions des idées nouvelles et des progress technologiques dangereuses". (The defenders of the established order aiming at the preservation of their privileges (nobility, high clergy) or their monopolies (guilds) consider spread of new ideas and technological progress to be dangerous). So also cultural and social attitudes of the stakeholders of the textile design sector led to a lack of attention for future orientated activity, which accelerated the decline of the studios due to loosing competitiveness compared to other textile design destinations. Consequently, even in creative SME sector it must be understood that constant attention and search for possibilities of improvement of products and services as well as inner structures combined with a focus on customer needs have to be considered to be priority goals for sustainable entrepreneurship.

An important observation in the case study is that the actors in the textile design sector enjoyed a professional education which was based on an apprenticeship in a design studio and on professional training at a textile training centres. Consequently the textile designers in Lyon did not visit a business school and their education and knowledge in management and business administration was very limited, especially in the fields of marketing, innovation and business strategy. In the interviews it was conjectured that the lack of deeper management knowledge together with an underdeveloped awareness about sustainability issues represented one important reason for the quick collapse of the textile design sector in Lyon. 
Finally it has to be mentioned that parts of the Lyon silk cluster survived by innovating or converging their initial products and by targeting to other markets. One import example represents the chemical industry in Lyon which contributed heavily to the silk cluster development with the production of colours and which nowadays still exists as chemical industry with a focus on pharmaceuticals.

\section{Conclusions}

The Lyon silk cluster followed in its development life-cycle patterns like every other cluster, consisting of phases of growth, saturation and decline. Over centuries the Lyon silk industry was an economic, sustainable endeavor for the Lyon region generating wealth and prosperity for several generations of workers. The decline and collapse of this cluster happened mainly within the last 50 years. First the silk production in Lyon region went down and moved to other destinations and later related cluster businesses, especially the textile design sector, nearly fully disappeared in Lyon.

The textile design sector represented a cornerstone of the outstanding global position of the Lyon silk cluster for a long time and it became a world leading place in creative business even after the decline of silk production in Lyon region. The case study gave an inside view into the development of the Lyon silk cluster and revealed reasons for its unsustainability and final collapse.

According to Pascual et al. (2011) sustainable development is a process that requires incremental and continuous improvement in order to fulfil the needs of current and future generations and to ensure that future generations will have the capability to enjoy a quality of life. Important reasons, especially for the decline of the textile design sector, can be found in cultural specifics, the entrepreneurial environment, the refuse to respond to technological and organizational innovations, and an underdeveloped awareness in strategic management issues.

The indifference towards open innovation models and the existence of complacence in large parts of the owners of the textile design studios avoided necessary future investments in innovations and educational institutions so that the development of the whole sector became unsustainable so that the textile design moved to other destinations and marginalized the Lyon textile design sector to an unimportant size. The decline process was accompanied by a low level of education of management and business knowledge in the textile design sector.

\section{References:}

Anselin, L.; Varga, A.; Acs, Z. 1997. Local geographic spillovers between university research and high technology innovations, Journal of Urban Economics 42: 422-448.

Bartl, M. 2008. White Paper: Open Innovation! Available on the Internet: <http://hyve.de/cms/upload/f_1599_WhitePaper_OpenInnovation.pdf>. [Accessed: 1 March 2014]

Becattini, G. 2002. From Marshall's to the Italian "Industrial Districts, in Quadrio Curzio, A.; Fortis, M. (Eds.). A Brief Critical Reconstruction, Complexity and Industrial Clusters Contributions to Economics, 83-106.

Benkenstein, M. 1998. Besonderheiten des Innovationsmanagements in Dienstleistungsunternehmen [Special features of innovation management in service companies], in Bruhn, M.; Meffert, H. (Ed.). Handbuch Dienstleistungsmanagement. Gabler: Wiesbaden, 689-703.

Bileišis, M. 2014. Public Sector Control as a Factor in Entrepreneurial Policy: the Case of Lithuania, Entrepreneurship and Sustainability Issues 1(3): 151-161. DOI: http://dx.doi.org/10.9770/jesi.2014.1.3(4)

Bluhm, K. 2008. Fach- und Führungskräfte in mittelständischen Unternehmen [Professionals and managers in medium-sized companies]. Institut für Soziologie der Universität Jena.

Bonetto, P.; Hofmann, B.; Prause, G. 2014. How Lyon lost its textile design sector - A case study about unsustainable entrepreneurship. Proceedings of the $13^{\text {th }}$ International Entrepreneurship Forum Conference: "Entrepreneurship and Development: The Idea of Inclusive Opportunity Creation”, 31 July - 2 August, 2014 Bogota, Colombia. 
Boschma, R. A.; Ter Wal, A. L. J. 2007. Knowledge networks and innovative performance in an industrial district: The case of a footwear district in the South of Italy, Industry and Innovation 14(2): 177-199.

Breschi, S.; Malerba, F.; Orsenigo, L. 2000. Technological regimes and Schumpeterian patterns of innovation, The Economic Journal 110 (463): 388-410.

Brown, T. 2008. Design Thinking, Harvard Business Review June: 1-10.

Chesbrough, H. 2003. Open Innovation: The New Imperative for Creating and Profiting from Technology. Boston: Harvard Business School Press.

Classen, N.; Carree, M.; Van Gils, A.; Peters, B. 2013. Innovation in Family and Non-Family SMEs: An Exploratory Analysis. Small Business Economics.

Cohen. B.; Winn, M. I. 2007. Market imperfections, opportunity, and sustainable entrepreneurship, Journal of Business Venturing 22(1): $29-49$.

Cooke, P.; Morgan, K. 1998. The Associational Economy: Firms, Regions, and Innovation. Oxford University Press.

De Alencar, L.M.; Almeida, H.N. 2013. Economic viability and sustainability of solidarity economy enterprises: a case study on the technological incubator of popular cooperatives of the Catholic University of Salvador, Entrepreneurship and Sustainability Issues 1(2): 92-98. DOI: http://dx.doi.org/10.9770/jesi.2013.1.2(3)

Drucker, F. 1985. Innovation and entrepreneurship: Practice and Principles. Harper \& Row.

Dzemyda, I.; Raudeliūniené, J. 2014. Sustainable youth entrepreneurship in conditions of global economy toward energy security, Entrepreneurship and Sustainability Issues 1(4): 247-256. DOI: http://dx.doi.org/10.9770/jesi.2014.1.4(7)

Figurska, I. 2014.Sustainable entrepreneurship: localization, acquiring and use of knowledge sources in competitive organization, Entrepreneurship and Sustainability Issues 1(4): 210-222. DOI: http://dx.doi.org/10.9770/jesi.2014.1.4(3)

Florida, R. 2002. The Rise of the Creative Class...and how it's transforming work, leisure, community and everyday life. Basic Books.

Foray, D.; David P. A.; Hall, B. H. 2011. Smart specialization from academic idea to political instrument, the surprising career of a concept and the difficulties involved in its implementation. Management of technology \& entrepreneurship institute. MTEI-working_paper-2011001 .

Fujita, M.; Krugman, P. 2004. The new economy geography: Past, present and the future, Papers in Regional Science 83(1): 139-164.

Gerlach, A. 2003. Sustainable entrepreneurship and innovation, in University of Leads, 2003 Corporate Social Responsibility and Environmental Management Conference, 30 June -1 July 2003. Leads: UK, 101-110.

Gertler, M.S.; Levitte, Y.M. 2005. Local nodes in global networks: The geography of knowledge flows in biotechnology innovation, Industry and Innovation 12(4): 487-507.

Gilsing, V.; Bekkers, R.; Bodas Freitas, I.; van der Steen, M. 2011. Differences in technology transfer between science-based and development-based industries, Transfer mechanisms and barriers 31: 638-647.

Giriūnienè, G. 2013. Public sector's subsidies to business - suitability valuation of labor market support measures, Entrepreneurship and Sustainability Issues 1(1): 37-44. DOI: http://dx.doi.org/10.9770/jesi.2013.1.1(4)

Goddard, J. 2000. The Response of HEIs to Regional Needs. OECD, Paris.

Hayek, F. A. 2002. Competition as a Discovery Procedure, The Quarterly Journal of Austrian Economics 5(3): 9-23.

Išoraite, M. 2013. Motivation tools though lenses of prospective employees, Entrepreneurship and Sustainability Issues 1(2): 116123. DOI: http://dx.doi.org/10.9770/jesi.2013.1.2(6)

Išoratė, M.; Steiblienè, L.; Mečèjienè, G. 2014. If obtained professional competences are suitable for sustainable entrepreneurship: case of Vilnius University of Applied Sciences, Entrepreneurship and Sustainability Issues 1(4): 239-246. DOI: http://dx.doi.org/10.9770/jesi.2014.1.4(6)

Jaffe, A.; Trajtenberg, M.; Henderson, R. 1993. Geographic Localization of Knowledge Spillovers as Evidenced by Patent Citations, The Quarterly Journal of Economics 108(3): 577-598. 
Korsakienè, R. 2013. Internationalization of construction firms: what strategy do they follow? Entrepreneurship and Sustainability Issues 1(2): 99-107. DOI: http://dx.doi.org/10.9770/jesi.2013.1.2(4)

Korsakienè, R.; Tvaronavičienè, M. 2014. Processes of economic development: case of Lithuanian real estate sector, Entrepreneurship and Sustainability Issues 1(3): 162-172. DOI: http//dx.doi.org/10.9770/jesi.2014.1.3(5)

Krugman, P. 1991. Increasing returns and economic geography, Journal of Political Economy 99(3): 483-499.

Laužikas, M.;Mokšeckienè. 2013. The role of creativity in sustainable business, Entrepreneurship and Sustainability Issues 1(1): 10-22. DOI: http://dx.doi.org/10.9770/jesi.2013.1(2)

Leroudier, E. 1908. Les dessinateurs et la soierie lyonnaise au XVIIIe siècle [The designers and the Lyon silk in the eighteenth century]. Revue d'Histoire de Lyons.

Lindqvist, G.; Ketels, K.; Sölvell, Ö. 2013. The Cluster Initiative Greenbook 2.0. Ivory Tower Publishers, Stockholm.

Litvaj, I.; Poniščiaková, O. 2014. Entrepreneurship and quality management, Entrepreneurship and Sustainability Issues 1(4): 204-209. DOI: http://dx.doi.org/10.9770/jesi.2014.1.4(2)

Marshall, A. 1920. Principles of Economics (Revised Edition). London: Macmillan; reprinted by Prometheus Books. ISBN 1-57392-1408.

Marsili, O. 2001. The Anatomy and Evolution of Industries: Technical Change and Industrial Dynamics. Edward Elgar Publishing Ltd., Cheltenham.

Meier zu Köcker, G. 2008. Clusters in Germany. Institute for Innovation and Technology.

Miller, L.E. 2004. Representing silk design: Nicholas Joubert de L'Hiberderie and Le dessinateur pour les etoffes d'or, d'argent et de soie (Paris, 1765), Journal of Design History 17(1): 29-53.

Pascual, O.; van Klink, A.; Rozo Grisales, J. 2011. Create Impact! Handbook for sustainable Entrepreneurship. Wuppertal Institute Collaborating Centre on Sustainable Consumption and Production (CSCP).

Porter, M. 2000. Location, Competition and Economic Development: Local Networks in a Global Economy, Economic Development Quarterly 14(1):15-34.

Porter, M. 1998. Clusters and the new economics of competition, Harvard Business Review 76: 77-90.

Rauch, A.; Frese, M.; Wang, Z-M.; Unger, J.; Lozada, M.; Kupcha, V.; Spirina, T. 2013. National culture and cultural orientations of owners affecting the innovation--growth relationship in five countries, Entrepreneurship \& Regional Development 25(9-10): 732-755.

Schmitt-Grohe, J. 1972. Produktinnovation. Verfahren und Organisation der Neuproduktplanung [Product innovation. Procedures and organization of new product planning]. Wiesbaden.

Schumpeter, J. 1911. Theorie der wirtschaftlichen Entwicklung: eine Untersuchung über Unternehmergewinn [Theory of economic development: a study of entrepreneurial profit]. Kapital, Kredit, Zins und den Konjunkturzyklus.

Sölvell, Ö. 2008. Clusters - Balancing evolutionary and constructive forces. Ivory Tower Publishers, Stockholm.

Tvaronavičienè, M. 2014. If industrial sector development is sustainable: Lithuania compared to the EU, Entrepreneurship and Sustainability Issues 1(3): 134-142. DOI: http://dx.doi.org/10.9770/jesi.2014.1.3(2)

Wahl, M. 2014. Sustainable Entrepreneurship: The Wolf ButterBack Case, Entrepreneurship and Sustainability Issues 1(4): $223-229$. DOI: http://dx.doi.org/10.9770/jesi.2014.1.4(4)

Wahl, M.; Prause, G. 2013. Toward understanding resources, competencies, and capabilities: business model generation approach, Entrepreneurship and Sustainability Issues 1(2): 67-80. DOI: http://dx.doi.org/10.9770/jesi.2013.1.2(1)

Wiederkehr, A. 1981. Le dessinateur pour les étoffes d'or, d'argent et de soie [The designer fabrics...]. PhD thesis. Université de Lyons II.

Young, W.; Tilley, F. 2006. Can business move beyond efficiency? The shift toward efficiency and equity in the corporate sustainability debate', Business Strategy and the Environment 15(6): 402-415.

Zhao, F. 2005. Exploring the synergy between entrepreneurship and innovation, International Journal of Entrepreneurial Behaviour \& Research 11: 25-41. 
Pierre BONETTO is Textile Design Entrepreneur. Research interests: textile-design, sustainable entrepreneurship, innovation.

Bernd HOFMANN is Associate Professor at Claude Bernard University of Lyon. Research interests: sustainable entrepreneurship, innovation, management of enterprises.

Gunnar PRAUSE is Professor for International Business in Tallinn School of Economics and Business Administration (TSEBA) of Tallinn University of Technology. Research interests: International Business, Entrepreneurship \& SME - Management, Logistics, Innovation. He is Board Member of the Centre for Business Research and Development at the Department of Business Administration of TSEBA, Board Member of the Institute of Cooperative Studies at Humboldt University Berlin, Board Member of Baltic China Science Park Network. He is author of more than 100 scientific articles.

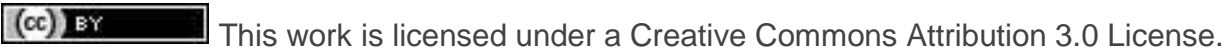

